\title{
Non-secretion of ABO blood group antigens as a host susceptibility factor in the spondyloarthropathies
}

\author{
RUTH SHINEBAUM，C CAROLINE BLACKWELL， PETER J G FORSTER， NIGEL P HURST, \\ DONALD $M$ WEIR, GEORGE NUKI
}

\begin{abstract}
Gram negative bacteria precipitate reactive arthritis and may be concerned in the pathogenesis of ankylosing spondylitis and other spondyloarthropathies. Susceptibility to many infectious agents is associated with $\mathbf{A B O}$ blood group or secretor state, or both. The distribution of the $\mathrm{ABO}$ blood group or secretor state, or both, was therefore determined in 87 patients with ankylosing spondylitis and 32 with other forms of spondyloarthropathy.

The prevalence of non-secretors was significantly increased in the total patient group $(54 / 114 ; 47 \%)$ and in the subgroup with ankylosing spondylitis $(41 / 84 ; 49 \%)$ compared with local controls $(89 / 334 ; 27 \%)(p<0.001)$. Other subgroups of patients showed a similarly increased prevalence of non-secretion (33-47\%). The distribution of $\mathrm{ABO}$ blood groups did not differ between patients and controls.
\end{abstract}

The association between non-secretor state and ankylosing spondylitis strengthens the hypothesis that ankylosing spondylitis is a form of reactive arthritis. It also suggests several pathogenic mechanisms which may be relevant to the initial hostparasite interaction in ankylosing spondylitis.

\section{Introduction}

An infectious aetiology for ankylosing spondylitis has been postulated on several occasions, and many workers consider this disease to be a form of reactive arthritis. ${ }^{12}$ The hypothesis that the aetiology of ankylosing spondylitis is related to the gut is based on the abnormalities of the bowel that occur in other spondyloarthropathies $^{3}$ and on analogy with the reactive arthritis that may occur after gastrointestinal infection. ${ }^{4}$ These associations suggest that Gram negative bacteria acting at the gut mucosal surface may be important in the pathogenesis of ankylosing spondylitis. Investigators have examined the role of faecal klebsiella ${ }^{5-7}$ and the interaction of these and similar organisms with HLA-B27, ${ }^{89}$ but no clear relation among enterobacteria, HLA-B27, and ankylosing spondylitis has emerged. It may therefore be pertinent to consider aspects of the host-parasite relation other than HLA-B27, and in particular those host factors associated with infection by Gram negative bacteria.

Blood group specificities of the ABO system are genetically determined, stable host characteristics which have been associated with susceptibility to some infectious diseases. The prevalence

\footnotetext{
Department of Bacteriology, University of Edinburgh Medical School, Edinburgh EH8 9AG

RUTH SHINEBAUM, BSC, PHD, research fellow

CCAROLINE BLACKWELL, BS, PHD, lecturer

DONALD M WEIR, MD, FRCPED, professor of microbial immunology

Rheumatic Diseases Unit, University of Edinburgh, Northern General Hospital, Edinburgh EHS $2 \mathrm{DQ}$

PETER J G FORSTER, MD, MRCP, senior registrar

NIGEL P HURST, PHD, MRCP, senior registrar

GEORGE NUKI, MB, FRCP, professor of rheumatology

Correspondence to: Dr Shinebaum.
}

of blood group $\mathrm{O}$ is increased in patients with typhoid, ${ }^{10}$ para- $\frac{\bar{O}}{\overline{\frac{O}{}}}$ typhoid, ${ }^{10}$ and cholera ${ }^{11}$; group $\mathrm{B}$ is increased in patients with $\overrightarrow{\mathrm{D}}$ gonorrhoea, ${ }^{12}$ chlamydial infections (unpublished observations), 2 urinary tract infection caused by Escherichia coli, ${ }^{13}$ and in children कs with Gram negative enteric infections ${ }^{14}$; and there are reports $\vec{O}$ of an increased prevalence of group A among patients with $\overrightarrow{\vec{H}}$ meningococcal meningitis. ${ }^{10}$ By contrast, a normal distribution of $\vec{\omega}$ blood groups is found among patients with diphtheria, brucellar $\bar{O}$ infections, and whooping cough. ${ }^{10}$ At least two infections associated with an increased prevalence of the B blood group, gonorrhoea and 0 chlamydia, may precipitate reactive arthritis. ${ }^{4}$

A second genetically controlled host characteristic which has of been associated with susceptibility to infection is the inability to $\%$ secrete the water soluble glycoprotein forms of the ABO blood $N$ group antigens. The prevalence of non-secretors is increased among $\infty$

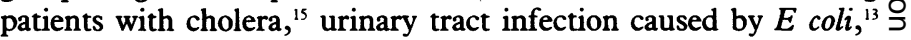
candidiasis, ${ }^{16}$ meningococcal meningitis, ${ }^{17}$ and pneumococcal $N$ infections, ${ }^{17}$ but not among those with tuberculosis, ${ }^{10}$ leprosy, ${ }^{10}$ or $C$ gonorrhoea. ${ }^{12}$ Though only a few studies have been reported, a $\stackrel{2}{5}$ pattern is emerging of an association between non-secretion of blood group antigens and susceptibility to infections of the mucosal surfaces.

These observations led us to examine the hypothesis that there would be an increased prevalence of blood group $B$ or non-secretor 0 state, or both, among patients with ankylosing spondylitis and other spondyloarthropathies. As concentrations of $\operatorname{IgA}$ (the immunoglobalin associated with protection of mucosal surfaces) are raised in ankylosing spondylitis, ${ }^{1819}$ and reportedly influenced by secretor $\stackrel{\circ}{\mathbb{D}}$ state, ${ }^{2021}$ we have also determined IgA concentrations in the serum $\stackrel{2}{\Rightarrow}$ and saliva of our patients.

\section{Patients and methods}

We studied 119 patients with clinically well defined spondylarthritides selected at random from the population attending outpatient clinics at the rheumatic diseases unit of the Northern General Hospital over two years. Patients were classified into four categories according to their medical $?$ history: ankylosing spondylitis (87 patients), reactive arthritis (22), and radiological sacroiliitis (with or without ankylosing spondylitis) 0 (a) associated with inflammatory bowel disease (three patients) or (b) associated with psoriasis (seven patients). Patients with ankylosing $N$ spondylitis fulfilled the New York criteria, ${ }^{22}$ and those with reactive arthritis $D$ fulfilled criteria for definite Reiter's disease ${ }^{23}$ (14 patients) or postinfective reactive arthritis ${ }^{24}$ (eight patients).

When possible patients' records were analysed for HLA state (55 patients) and for a history of ocular inflammation (101) or inflammatory arthritis of $\omega$ peripheral joints (100). A single sample of venous blood and saliva was collected from each of 113 patients. A further five patients provided blood 0 but no saliva, and one provided saliva only.

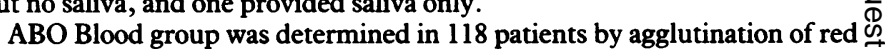
cells with appropriate antisera. Secretor state was determined in 114 patients by the haemagglutination inhibition assay using saliva, as described. ${ }^{25}$ Controls were 334 randomly selected normal people attending the Edinburgh blood donor centre during 1981. ${ }^{13}$ IgA Concentrations in samples of $\frac{\rho}{\mathbb{D}}$ serum (98 patients) and saliva (97) which had been stored at $-20^{\circ} \mathrm{C}$ were $\varrho$ determined by single radial immunodiffusion with commercially prepared plates (Behring Diagnostic, Hounslow).

Statistical analyses were by $\chi^{2}$ test, using Yates's correction for continuity in fourfold tables. Relative risk (odds ratio) was calculated by simple proportion. Ninety five per cent confidence limits for relative risk were $\frac{\overline{ }}{\bar{T}}$ calculated using natural logarithm conversion. 


\section{Results}

Tables I and II show the distribution of $\mathrm{ABO}$ blood group and secretor state in the patients and controls. There was a significant increase $(p<0.001)$ in the proportion of non-secretors in the total patient group $(54 / 114 ; 47 \%)$ compared with the local control population $(89 / 334 ; 27 \%)$. The relative risk for spondyloarthropathy in non-secretors was $2 \cdot 5$ ( $95 \%$ confidence interval $1 \cdot 6-3 \cdot 8)$. The increase in non-secretors was evident in all subgroups of patients and achieved statistical significance $(p<0.001)$ in both the total group with sacroilitis $(46 / 97 ; 47 \%)$-that is, all patients with radiological sacroiliitis irrespective of disease category -and the group with ankylosing spondylitis $(41 / 84 ; 49 \%)$. Nine out of 20 patients with reactive arthritis

\section{Discussion}

Secretion of blood group antigens into body fluids is a dominant, genetically determined characteristic. Roughly $25 \%$ of people throughout the world are recessive for the secretor $(\mathrm{Se})$ gene, genotype $s e, s e$, though the proportion varies in some populations. ${ }^{26}$ Our control group shows that the local population had a proportion of non-secretors similar to but slightly higher than the expected frequency, as is usual among populations of Celtic origin.

This study found a significantly increased prevalence of nonsecretors of blood group antigens among patients with spondylo-

TABLE I-Distribution of ABO blood group among patients with spondyloarthropathies

\begin{tabular}{|c|c|c|c|c|c|c|c|}
\hline & \multirow{2}{*}{$\begin{array}{c}\text { No } \\
\text { tested }\end{array}$} & \multicolumn{4}{|c|}{ No (\%) with blood group } & \multirow[b]{2}{*}{$\chi^{2} v$ control } & \multirow[b]{2}{*}{$\mathbf{p}$} \\
\hline & & $\mathrm{O}$ & $\mathbf{A}$ & B & $\mathbf{A B}$ & & \\
\hline $\begin{array}{l}\text { Control population } \\
\text { Total patient group } \\
\text { Total group with sacroiliitis } \\
\text { Ankylosing spondylitis } \\
\text { Reactive arthritis } \\
\text { Sacroiliitis associated with inflammatory bowel disease } \\
\text { Sacroiliitis associated with psoriasis }\end{array}$ & $\begin{array}{r}334 \\
118 \\
99 \\
86 \\
22 \\
3 \\
7\end{array}$ & $\begin{array}{r}173(52) \\
49(42) \\
41(41) \\
35(41) \\
10(45) \\
1(33) \\
3(43)\end{array}$ & $\begin{array}{r}104(31) \\
47(40) \\
39(39) \\
34(40) \\
8(36) \\
2(67) \\
3(43)\end{array}$ & $\begin{array}{l}42(13) \\
17(14) \\
14(14) \\
13(15) \\
4(18) \\
0 \\
0\end{array}$ & $\begin{array}{l}15 \\
5\end{array}$ & $\begin{array}{l}3 \cdot 93 \\
3 \cdot 44 \\
3 \cdot 51 \\
\text { N/A } \\
\text { N/A } \\
\text { N/A }\end{array}$ & $\begin{array}{l}>0.10 \\
>0.10 \\
>0.10\end{array}$ \\
\hline
\end{tabular}

$\mathrm{N} / \mathrm{A}=$ Not applicable

*All patients with radiological sacroiliitis irrespective of disease category.

TABLE II-Secretor state of patients with spondyloarthropathies

\begin{tabular}{lrcccc}
\hline & $\begin{array}{c}\text { No } \\
\text { tested }\end{array}$ & $\begin{array}{c}\text { No(\%) of } \\
\text { non-secretors }\end{array}$ & $\chi^{2} v$ control & p & $\begin{array}{c}\text { Relative risk } \\
(95 \% \text { confidence interval) }\end{array}$ \\
\hline Control population & 334 & $89(27)$ & & & \\
Total patient group & 114 & $54(47)$ & $15 \cdot 85$ & $<0 \cdot 001$ & $2 \cdot 5(1 \cdot 6-3 \cdot 8)$ \\
Total group with sacroiliitis & 97 & $46(47)$ & $14 \cdot 13$ & $<0 \cdot 001$ & $2 \cdot 5(1 \cdot 5-4 \cdot 2)$ \\
$\quad$ Ankylosing spondylitis & 84 & $41(49)$ & $14 \cdot 37$ & $<0 \cdot 001$ & $2 \cdot 6(1 \cdot 5-4 \cdot 6)$ \\
Reactive arthritis & 20 & $9(45)$ & $2 \cdot 32$ & $>0 \cdot 10$ & $2 \cdot 3(0 \cdot 7-7 \cdot 0)$ \\
Sacroilitis associated with inflammatory bowel disease & 3 & $1(33)$ & N/A & & \\
Sacroilitis associated with psoriasis & 7 & $3(43)$ & N/A & & \\
\hline
\end{tabular}

$\mathrm{N} / \mathrm{A}=$ Not applicable.

*All patients with radiological sacroiliitis irrespective of disease category.

(45\%) and three out of seven with sacroiliitis associated with psoriasis (43\%) were non-secretors, proportions similar to that in the group with ankylosing spondylitis.

There was no evidence that the distribution of $\mathrm{ABO}$ blood group among the patients was different from that among local controls $(p>0 \cdot 10)$, and in particular no evidence of an increased prevalence of blood group B. The blood group distribution was similar in each disease category.

Analysis of $\operatorname{IgA}$ concentrations and clinical features in the total patient group showed few differences between secretors and non-secretors. There was no evidence of differences in serum or salivary IgA concentrations between the two groups (table III); eye lesions were more common among

TABLE III-Secretor state and geometric mean IgA concentrations (SD in parentheses) in patients with spondyloarthropathies. Values are IU/ml

\begin{tabular}{lcc}
\hline & Serum IgA & Salivary IgA \\
\hline Secretors ( $n=51$ serum, 50 salivary) & $176 \cdot 8(1 \cdot 5)$ & $4 \cdot 3(1 \cdot 8)$ \\
Non-secretors $(n=47$ serum, 47 salivary) & $172 \cdot 6(1 \cdot 9)$ & $4 \cdot 3(1 \cdot 7)$
\end{tabular}

non-secretors $(17 / 48 ; 35 \%)$ than secretors $(11 / 53 ; 21 \%)$, but not significantly so; peripheral joint disease was less common among non-secretors $(24 / 47 ; 51 \%)$ than secretors $(35 / 53 ; 66 \%)$, but again the difference was not significant.

Data on HLA typing were available for 55 patients; 50 were B27 positive and five B27 negative. Three of the B27 negative patients were non-secretors and two were secretors. arthropathies. There are several possible explanations. The gene for secretion may be linked to another which affects susceptibility to disease or immune responsiveness; the product of the $S e$ gene may modify antigens on cells of host or parasite; or blood group antigens may themselves be important in determining susceptibility to these diseases.

Family studies of ankylosing spondylitis and reactive arthritis show that genetic determinants additional to HLA-B27 are necessary for the development of these diseases. ${ }^{27}{ }^{28} \mathrm{It}$ has been suggested that such additional genes are concerned with the functioning of the immune system, and it is therefore tempting to speculate that there is a genetic link between secretor state and immune responsiveness. There is evidence that the $S e$ gene forms part of a linkage group on chromosome 19 with complement component $\mathrm{C} 3$, but this is the only known immunological function coded for nearby: genes coding for HLA and most other immune determinants are on chromosome $6 .{ }^{29} \mathrm{~A}$ single report that salivary IgA concentrations are reduced in non-secretor adults ${ }^{21}$ suggests that IgA deficiency may be responsible for increased susceptibility to infection in nonsecretors, which in turn might predispose to reactive arthritis and spondylarthritis. Our data do not support such a hypothesis. Our studies suggest that non-secretion increases the relative risk for ankylosing spondylitis and reactive arthritis, albeit only twofold to threefold. Hence the gene determining secretor state is possibly in itself a subsidiary determinant for these diseases. Family studies will be required to assess the combined relative risk of being HLA-B27 positive and the non-secretor genotype se,se.

The biological role of the $S e$ gene is not clear, but there is 
biochemical evidence that $S e$ is a structural gene encoding a specific fucosyltransferase. At least two such enzymes are concerned with the synthesis of blood group specificities, adding fucose residues to one of several types of precursor chain. Evidence suggests that the $S e$ gene product preferentially uses the type I chain as substrate. ${ }^{30}$ Possibly this enzyme glycosylates other structures such as HLA or other cell surface antigens, or even antigens on invading microorganisms. Any such modification of antigens on host tissue or infecting agent might affect the balance of the initial host-parasite interaction.

The main differences between secretors and non-secretors are related to the antigens present in their body fluids. With the exception of the extremely rare Bombay phenotype, all secretors have the water soluble form of the $\mathrm{H}$ antigen (the antigen of blood group $\mathrm{O}$ ), and the $94 \%$ who possess the Lewis blood group gene have Le $e^{b}$ antigen. People of the appropriate blood groups will also secrete water soluble forms of the $A$ and $B$ antigens. Non-secretors do not have $\mathrm{A}, \mathrm{B}, \mathrm{H}$, or $\mathrm{Le}^{\mathrm{b}}$ antigens in their body fluids, but the $94 \%$ with the Lewis gene have a different form of the Lewis antigen, $\mathrm{Le}^{\mathrm{a}}$. ABH antigens occur in two forms, a glycolipid which forms part of the structure of a cell and a glycoprotein which is found in body fluids. Lewis antigens occur as glycolipids in the plasma and as glycoproteins in secretions; they do not form part of the structure of cells but are passively adsorbed to cell surfaces.

Much epidemiological evidence suggests that ankylosing spondylitis and reactive arthritis occur in genetically predisposed subjects after exposure to micro-organisms. Finding an association between secretor state and spondyloarthropathies suggests a possible role for blood group antigens in these diseases. Nonsecretion appears to be a marker associated with infections of the mucosal surfaces ${ }^{131516}$ and may be important in the colonisation stages of an infectious process. We suggest two models to explain the increased susceptibility of non-secretors to initial infection: Le $\mathrm{e}^{\mathrm{a}}$ in the body fluids of non-secretors may act as a receptor for infecting micro-organisms; or $\mathrm{H}$ or $\mathrm{Le}^{\mathrm{b}}$, or both, in the body fluids of secretors may inhibit the attachment of organisms. These two mechanisms are not mutually exclusive. It is unlikely that water soluble forms of the $A$ and $B$ antigens play $a$ part in the spondyloarthropathies, as our studies showed no association between these blood groups and ankylosing spondylitis or reactive arthritis.

There is at present little direct evidence that the ABO or Lewis blood groups act as receptors for micro-organisms. Nevertheless, antigens of other blood group systems do act in this way, ${ }^{3132}$ and recent work from our laboratory has identified the Le antigen as a receptor for certain strains of Candida.$^{33}$ Indirect evidence for a receptor role for these antigens comes from finding that $E$ coli binds in greater numbers to non-secretor than secretor cells, ${ }^{34}$ and from studies showing that attachment of micro-organisms may be inhibited by glycocompounds in body secretions. ${ }^{35}{ }^{36}$ Experiments are under way in our laboratory to see whether any of these mechanisms are operative in the interaction of arthritogenic Gram negative bacteria with secretor and non-secretor cells of patients with ankylosing spondylitis and controls.

Finding that non-secretion is associated with ankylosing spondylitis and reactive arthritis, together with the accumulating evidence of an association between non-secretion and mucosal surface infections, strengthens the hypothesis that ankylosing spondylitis is a form of reactive arthritis.

Though the increased relative risk for spondylarthritis associated with non-secretion is less than that associated with HLA-B27, non-secretion is nevertheless a host susceptibility factor for these diseases. Moreover, it may be particularly important in pointing the way to our understanding of the pathogenetic mechanisms in the initiation of disease in susceptible people.
This work was supported by a project grant from the Arthritis and Rheumatism Council. We thank the Edinburgh and South East Scotland Blood Transfusion Service for essential reagents and Dr R Prescott, of th University of Edinburgh, for statistical advice. We also thank Mrs M Cole for help in preparing the manuscript.

\section{References}

1 Ebringer A. The link between genes and disease. New Scientist 1978;79:865-7.

2 Kinsella TD, Fritzler MJ, McNeil DJ. Ankylosing spondylitis. A disease in search of microbes f Rheumatol 1983;10:2-4.

3 Neumann V, Wright V. Arthritis associated with bowel disease. Clin Gastroenterol 1983;12:767-95.

4 Hind CRK. Reactive arthritis. Postgrad Med f 1982;58:131-7.

5 Ebringer R, Cooke D, Cawdell DR, Cowling P, Ebringer A. Ankylosing spondylitis: klebsielk and HL-A B27. Rheumatol Rehabil 1977;16:190-6.

6 Eastmond CJ, Willshaw HE, Burgess SEP, Shinebaum R, Cooke EM, Wright V. Frequency $\mathbb{B}$ faecal Klebsiella aerogenes in patients with ankylosing spondylitis and controls with respect tog individual features of the disease. Ann Rheum Dis 1980;39:118-23.

7 Warren RE, Brewerton DA. Faecal carriage of klebsiella by patients with ankylosing spondylitis and rheumatoid arthritis. Ann Rheum Dis 1980;39:37-44.

8 Geczy AF, Yap J. A survey of isolates of Klebsiella pneumoniae which cross-react with an HLA-B27-associated cell-surface structure on the lymphocytes of paticnts with ankylosine HLA-B27-associated cell-surface struct
spondylitis. $\mathcal{I}$ Rheumatol 1982;9:97-100.

9 Beaulieu A, Rousseau F, Israel-Assayag E, Roy R. Klebsiella related antigens in ankylosin spondylitis. $\mathcal{I}$ Rheumatol 1983;10:102-5.

10 Mourant AE, Kopec AC, Domaniewska-Sobczak K. Blood groups and diseases: a study $\frac{\overrightarrow{\mathcal{C}}}{\mathrm{C}}$ associations of diseases with blood groups and other polymorphisms. Oxford: Oxford Universityo Press, 1978.

11 Barua D, Paguio AS. ABO blood groups and cholera. Ann Hum Biol 1977;4:489-92.

12 Kinane DF, Blackwell CC, Winstanley FP, Weir DM. Blood group, secretor status, an susceptibility to infection by Neisseria gonorrhoeae. Br $\mathcal{f}$ Vener Dis 1983;59:44-6.

13 Kinane DF, Blackwell CC, Brettle RP, Weir DM, Winstanley FP, Elton RA. ABO blood groun secretor state, and susceptibility to recurrent urinary tract infection in women. $\mathrm{Br} M e d \mathscr{D}_{0}$ 1982;285:7-9.

14 Robinson MG, Tolchin D, Halpern C. Enteric bacterial agents and the ABO blood groups. Am 9 Hum Genet 1971;23:135-45.

15 Chaudhuri A, Das Adhikary CR. Possible role of blood-group secretory substances in th aetiology of cholera. Trans R Soc Trop Med Hyg 1978;72:664-5.

aetiology of cholera. Trans R Soc Trop Med Hyg 1978;72:664-5.
16 Blackwell CC, Thom SM, Weir DM, Kinane DF, Johnstone FD. Host-parasite interaction underlying non-secretion of blood group antigens and susceptibility to infections by Candide underiying non-secretion of bood group antigens and susceptibility to infections by Candide
albicans. In: Lark DL, ed. Protein-carbohydrate interactions in biological systems. London
Academic Press, 1986:231-3. Academic Press, 1986:231-3.

17 Blackwell CC, Jonsdottir K, Hanson $M$, et al. Non-secretion of ABO antigens predisposing to infection by Neisseria meningitidis and Streptococcus pneumoniae. Lancet 1986;ii:284-5.

18 Veys EM, Van Laere M. Serum IgG, IgM and IgA levels in ankylosing spondylitis. Ann Rheum $D$, 1973;32:493-6.

19 Laurent MR, Panayi GS. Acute-phase proteins and serum immunoglobulins in ankylosing spondylitis. Ann Rheum Dis 1983;42:524-8.

20 Grundbacher FJ. Immunoglobulins, secretor status and the incidence of rheumatic fever and rheumatic heart disease. Hum Hered 1972; 25:399-404.

21 Waissbluth JG, Langman MJS. ABO blood groups, secretor status, salivary protein, and serum and salivary immunoglobulin concentrations. Gut 1971;12:646-9.

22 Bennett PH, Burch TA. New York symposium on population studies in the rheumatic disease new diagnostic criteria. Bull Rheum Dis 1967;17:453-8. 3 Willkens RF, Arnett FC, Bitter T, et al. Reiter's syndrome. Evaluation of preliminary criteria foo
definite disease. Arthritis Rheum 1981;24:844-9.

24 Olhagen B. Postinfective or reactive arthritis. Scand $\mathcal{f}$ Rheumatol 1980;9:193-202.

25 Mollison PL. Blood transfusion in clinical medicine. Oxford: Blackwell Scientific Publications 1979:414-82.

26 Mourant AE, Kopec AC, Domaniewska-Sobczak K. The distribution of the human blood groups an other polymorphisms. London: Oxford University Press, 1976.

27 Woodrow JC. Genetic analysis of ankylosing spondylitis. In: Ziff M, Cohen SB, eds. Th spondyloarhhropathies. Advances in inflammation research. Vol 9. New York: Raven Press 1985:75-82.

28 Brewerton DA. HLA-B27 and the inheritance of susceptibility to rheumatic disease. Arthrits Rheum 1976;19:656-68.

29 McKusick VA. The human gene map. In: O'Brien SJ, ed. Genetic maps. Vol 2. New York: Colf Spring Harbor Laboratory, 1983:327-49. $30 \mathrm{Kumazaki} \mathrm{T}$, Yoshida A. Biochemical evidence that secretor gene, Se, is a structural gene

31 Kallenius G, Mollby R, Svensson SB, et al. The pk antigen as receptor for the haemagglutinin of pyelonephritic Escherichia coli. FEMS Microbiological Letters 1980;7:297-302.

32 Miller LH, Mason SJ, Dvorak JA, McGinniss MH, Rothman IK. Erythrocyte receptors fo (Plasmodium knowlesi) malaria: Duffy blood group determinants. Science (New York 1975;189:561-3.

33 May SJ, Blackwell CC, Weir DM. Non-secretion of blood group antigens and susceptibility 0 Candida albicans: the role of Lewis blood group antigens [Abstract]. I Dent Res 1986;65:503.N

34 Lomberg H, Cedegren B, Leffler H, Nilsson B, Carlstrom A-S, Svanborg-Eden C. Influence of blood group on the availability of receptors for attachment of uropathogenic Escherichia colP Infect Immun 1986;51:919-26.

35 Williams RC, Gibbons RJ. Inhibition of streptococcal attachment to receptors on human bucc epithelial cells by antigenically similar salivary glycoproteins. Infect Immun 1975;11:711-8.

36 Holmgren J, Svennerholm A-M, Ahren C. Non-immunoglobulin fraction of human milk inhibic bacterial adhesion (hemagglutination) and enterotoxin binding of Escherichia coli and Vibriq cholerae. Infect Immoun 1981;33:136-41.

(Accepted 18 November 1986) 